\title{
Business Cycles, Migration and Health SECOND DRAFT
}

\author{
Timothy J. Halliday* \\ University of Hawaii at Manoa
}

August 5, 2005

\begin{abstract}
This paper uses data from the PSID to investigate how selective migration affects the relationship between business cycles and health. We show that, among the healthy, migration is used to insure against macroeconomic fluctuations. However, among the unhealthy, there is no relationship between migration and business cycles. In other words, illness erases a person's ability to use migration to hedge against business cycle fluctuations. This suggests that recessions should induce an out-migration of disproportionately healthy people from economically depressed areas. This implies that - ceterus paribus - mortality and morbidity rates should be counter-cyclical.
\end{abstract}

JEL Classification: J10, J61

*Address: 2424 Maile Way; Saunders Hall 533; Honolulu, HI 96822; USA. Tele: (808) 956 - $8615 . \quad$ E-mail: halliday@hawaii.edu. WWW: www2.hawaii.edu/ halliday. 


\section{Introduction}

In this paper, we explore how selective migration affects the relationship between business cycles and health. Migration may be an important factor when thinking about this relationship, because it is well-understood that cities and states that experience economic declines, also experience large out-migrations of people (Blanchard and Katz 1992). What this suggests is that this relationship will depend crucially on exactly who migrates in response to economic shocks. If it is the case that the people that migrate out of depressed cities tend to be healthier, then this suggests that, ceterus paribus, morbidity and mortality rates in those areas should decline during recessions. In contrast, if it is the case that unhealthy people tend to migrate out of depressed cities, then we should expect the opposite.

To look into this issue, we employ data on geographic mobility, Self Reported Health Status (SRHS) and local unemployment rates from the Panel Study of Income Dynamics (PSID). We find that poor health creates additional costs which impede a person's ability to migrate. We also show that people tend to migrate from areas with high unemployment to areas with low unemployment suggesting that migration is used to hedge against business cycle fluctuations. However, we find that poor health erases a person's ability to use migration to hedge against macroeconomic shocks. Consequently, our results suggest that recessions induce an out-migration of people who are disproportionately healthy. Finally, we conduct some robustness checks which suggest that reverse causality from migration to health is not impacting our findings.

These results shed an interesting light on recent work by Ruhm (2000) who shows that mortality rates decline during recessions. Ruhm argues that this relationship may be causal. His 
reasoning is that economic lulls may actually improve health-related behaviors since recessions should tighten the household's budget constraint, thereby, resulting in people smoking fewer cigarettes and should relax time constraints, thereby, allowing people to exercise more. Ruhm (2000 and 2005) provides evidence that, indeed, health-related behaviors do improve during economic declines. However, if these improvements actually do reduce mortality rates during recessions, their effects would have to be sufficiently strong so that they could overcome the effects of out-migration of healthy people which also occurs during economic declines.

The balance of this paper is organized as follows. Section 2 describes the data. Section 3 describes our estimation equation. Section 4 describes the main results. Section 5 provides some robustness checks. Section 6 concludes..

\section{Data}

We use data on geographic mobility, SRHS, county unemployment rates and other control variables from the PSID. Our data cover the years 1984 to $1993 .^{1} \quad$ The PSID only has data on SRHS for the heads of the household and their wives. Consequently, throughout this analysis, we restrict our attention to household heads and their spouses. Since people primarily migrate in response to business cycle fluctuations in order to relocate to areas with better employment opportunities, we further restrict our attention to individuals who are below retirement age i.e. younger than age 65 .

Table 1 reports the descriptive statistics from our sample. Our migration variable, "Moved?,"

\footnotetext{
${ }^{1}$ SRHS data are not available prior to 1984. Location data and unemployment rates are not available after 1993.
} 
is a dummy variable indicating that the individual has changed states across two successive survey years. $^{2}$ This migration variable is commonly used in the literature on internal migration within the US. ${ }^{3}$ Looking at the table, we see that $5.8 \%$ of the individual-time observations changed states across survey years. Thus, migration is quite common in our data. Our measure of health status is SRHS: a categorical variable that takes on integer values between 1 and 5 . 1 means that the individual perceives that their health is excellent; 2 is very good; 3 is good; 4 is fair; 5 is poor. These data are subjective measures. However, there is an extensive literature that has shown a strong link between SRHS and more objective health outcomes such as mortality and the prevalence of disease (Mossey and Shapiro 1982; Kaplan and Camacho 1983; Idler and Kasl 1995; Smith 2003). To measure macroeconomic conditions, we use the unemployment rate in the individual's county of residence. Unemployment rates are probably the most appropriate measure of local macroeconomic conditions in our context given that Blanchard and Katz (1992) concluded that migration in response to economic shocks is more closely associated with changes in unemployment than it is with changes in consumption wages.

\section{Estimation Equation}

Our estimation equation is:

\footnotetext{
${ }^{2}$ Unfortunately, data on county of residence is considered sensitive by PSID and, thus, is not publicly available. Accordingly, our migration variable is whether or not the individual has changed states across successive time periods rather than whether or not they have changed counties.

${ }^{3}$ See Gabriel and Schmitz (1994) and Borjas, Bronars and Trejo (1992) for examples.
} 


$$
\begin{gathered}
M_{i, t}= \\
\alpha+B_{i, t} \beta+G_{i, t} \gamma+U_{i, t} \phi_{0}+U_{i, t-1} \phi_{1}+ \\
U_{i, t} * B_{i, t} \eta_{0}+U_{i, t-1} * B_{i, t} \eta_{1}+U_{i, t} * G_{i, t} \varphi_{0}+U_{i, t-1} * G_{i, t} \varphi_{1}+X_{i, t} \theta+\varepsilon_{i, t} .
\end{gathered}
$$

$M_{i, t}$ is the variable "Moved?." $B_{i, t}$ is a dummy variable indicating fair or poor health at time $t$. $G_{i, t}$ is dummy variable indicating excellent or very good health at time $t .{ }^{4}$ The variables on health status allow us to see how health induces selection in migration. $U_{i, t}$ is the unemployment rate in the individual's county of residence at time $t$. We include the unemployment rate at times $t$ and $t-1$. As noted by Blanchard and Katz (1992), one of the main mechanisms by which regions adjust to employment shocks is migration. Accordingly, we expect that $\phi_{0}<0$ and $\phi_{1}>0$ so that people migrate from areas with high unemployment to areas with low unemployment. The interaction terms in the regression equation allow us to see whether people that leave states as a consequence of employment shocks are disproportionately healthier than those who stay behind. $X_{i, t}$ contains other control variables such as age, functions of lagged labor income, gender dummies, race dummies, education dummies, year dummies and state dummies. We use functions of lagged income to address the possibility that current migration decisions will affect future income. Inclusion of $X_{i, t}$ allows us to ensure that our results are not being driven by an omitted variables bias. We adjust all standard errors for clustering on individuals to allow for serial correlation in $\varepsilon_{i, t}$ within individuals. $^{5}$

\footnotetext{
${ }^{4}$ In Section 5, we also experiment with using lags of the health variables to address any possibility of migration impacting health.

${ }^{5}$ We refer the reader to pp. 329-331 of Wooldridge (2000) for a discussion.
} 


\section{Core Results}

Our main results are reported in Table 2. In column 1, we only include variables on health status, unemployment and age. Consistent with Halliday (2004), we see that health induces selection in migration so that good health is associated with a higher probability of migration and bad health is associated with a lower probability. Looking at the fourth row from the bottom of the table, we see that the health variables are jointly significant at levels higher than 99\%. We see that moving from bad health to good health raises the probability of migration by roughly 0.01 percentage points. Since the unconditional probability of migration in our data is 0.058, this constitutes a large percentage increase. Turning to the unemployment variables, we see that the estimates of the coefficients on current unemployment rates are negative, whereas those on lagged unemployment are positive. This is consistent with what we would expect as this indicates that people tend to migrate from areas with high unemployment to areas with low unemployment. The interpretation of these coefficients is that if an individual is living in a state with a low unemployment rate at time $t$ then there is a higher probability that he migrated to that state between $t-1$ and $t$ than if the time $t$ unemployment rate were high. In other words, people tend not to move to depressed states. Conversely, if an individual is living in a state with a high unemployment rate in $t-1$ then there is a higher probability that he will change states in the coming time period. This finding is consistent with previous research by Blanchard and Katz (1992).

In column 2, we add interactions between health and unemployment rates. As indicated by the third row from the bottom in the table, all the coefficients on unemployment rates and their 
associated interactions are jointly significant at levels greater than $99 \%{ }^{6}$ Next, we see that the interaction between bad health and current unemployment is positive and the interaction with lagged unemployment is negative suggesting that the relationship between employment shocks and migration is attenuated by poor health. In addition, the coefficients on the unemployment variables and the coefficients on their associated interactions with Bad Health are roughly equal and opposite so that illness appears to erase a person's ability to insure against business cycle fluctuations through migration. Indeed, testing the nulls that $H_{0}: \phi_{0}+\eta_{0}=0$ and that $H_{0}: \phi_{1}+\eta_{1}=0$, we obtain $p$-values of 0.574 and 0.595 , respectively. Finally, we see that the interaction between good health and current unemployment is negative so that good health adds on to the effect of business cycle fluctuations on migration. The interaction with lagged unemployment is essentially zero.

In columns 3 and 4, we include more regressors to ensure that our results are robust to additional controls. In column 3, we include a comprehensive set of controls for (lagged) labor supply, (lagged) income, gender, race and education. Compared to column 2, we see that the effects of health on migration are attenuated somewhat, but are still positive and highly significant. However, the unemployment variables and their associated interactions remain unchanged and are still jointly significant at levels greater than $99 \%$. In column 4 , we add year and state dummies and see that the results are unaffected. ${ }^{7}$

\footnotetext{
${ }^{6}$ It is important when interpreting these results to pay careful attention to the tests of joint significance at the bottom of the table. Looking solely at $t$-statistics to judge the significance of the results will tend to be misleading when assessing the importance of several variables, particularly, when these variables include interactions of one another which tends to induce correlation across coefficient estimates. Accordingly, it is important to pay special attention to the $F$-tests of joint significance as these tests have better power.

${ }^{7}$ All of the empirical results in this paper include the Survey of Economic Opportunities (SEO) - an oversample of economically disadvantaged people in the PSID. Since the households in the SEO were chosen because they were poor, the selection that it induces is endogenous and, thus, conventional weighting schemes are not appropriate for the SEO. Consequently, some such as Lillard and Willis (1978) have proposed dropping the SEO
} 


\section{Robustness Checks}

In Table 3, we investigate the robustness of our results to different partitions of SRHS. The table reports the results from three regressions, each of which has the same control variables as column 4 of Table 2. The first column of Table 3 contains both Good Health $\left(G_{i, t}\right)$ and Bad Health $\left(B_{i, t}\right)$ and is, thus, identical to column 4 of Table 2.

In column 2 of Table 3, we include only Bad Health and its associated interactions. We see that once we exclude Good Health from the regression, the coefficient of Bad Health rises in absolute terms; its estimate in column 1 is -0.004 , whereas its estimate in column 2 is -0.012 . In addition, the interactions between Bad Health and the unemployment rates now have higher t-statistics, but the point-estimates are similar. The interaction terms in column 2 are jointly significant at the $99 \%$ level and are, once again, of equal magnitudes, but of the opposite sign as the unemployment coefficients.

In column 3, we exclude Bad Health, but include Good Health. The point-estimate on Good Health is roughly the same, but the coefficient is more tightly estimated. As we saw before, the interaction between Good Health and the time $t$ unemployment rate is negative and, thus, indicates that the effects of recessions on migration are magnified for healthier people.

In Table 4, we replicate the regressions in Table 3 except that we now use lagged health

from the sample. Others, however, such as Hyslop (1999) and Meghir and Pistaferri (2004) have included the SEO in their analyses. We also include the SEO as its exclusion substantially reduces our sample size. We do so because the complicated nature of our regression equation with all of its lagged variables and associated interactions requires a substantial number of observations for precise estimates. However, we also generated a set of results that excludes the SEO and, while the estimates were (not surprisingly) slightly less precise, the estimates were very similar. Essentially, the only effect of dropping the SEO is higher standard errors. 
instead of current health. ${ }^{8}$ We do this to address any concerns that migration may have a contemporaneous impact on health. The use of lagged health measures health prior to the occurrence of the move and, thus, quells any concerns of reverse causality. However, due to the addition of more lagged variables to the estimation equation, we expect our estimates to be slightly less precise. Thus, addressing these concerns should come at a cost in terms of efficiency.

In column 1, we include both lags of Good Health $\left(G_{i, t-1}\right)$ and Bad Health $\left(B_{i, t-1}\right)$. The coefficient on Good Health is positive and highly significant and the coefficient on Bad Health is also positive (not negative as we have been seeing), but insignificant. The interactions between the health variables and the unemployment variables are consistent with Table 2 - although, the point-estimates are now less precise, as we would expect. The only anomaly among the interaction terms is the coefficient on the interaction between lagged unemployment and Good Health $\left(\varphi_{1}\right)$ which is now larger in absolute value with the wrong sign. Presumably, this reflects random variation. ${ }^{9} \quad$ Nevertheless, the other three interactions have the same signs and magnitudes that we have been seeing and the tests of joint significance on the interactions are significant at a level higher than $99 \%$.

In column 2, we exclude Good Health. The coefficient on Bad Health is now negative and significant with a $t$-statistic of -1.85 . The interactions between Bad Health and unemployment have the same point-estimates as we have been seeing. However, while the unemployment

\footnotetext{
${ }^{8}$ Accordingly, we now estimate

$$
\begin{gathered}
M_{i, t}= \\
\alpha+B_{i, t-1} \beta+G_{i, t-1} \gamma+U_{i, t} \phi_{0}+U_{i, t-1} \phi_{1}+ \\
U_{i, t} * B_{i, t-1} \eta_{0}+U_{i, t-1} * B_{i, t-1} \eta_{1}+U_{i, t} * G_{i, t-1} \varphi_{0}+U_{i, t-1} * G_{i, t-1} \varphi_{1}+X_{i, t} \theta+\varepsilon_{i, t} .
\end{gathered}
$$

${ }^{9}$ The estimate of this interaction in column 3 of Table 4 is approximately zero providing evidence that this is, indeed, the case.
} 
variables together with their interactions with Bad Health are jointly significant at the $99 \%$ level, the interaction terms alone are not jointly significant - despite having unchanged pointestimates. Once again, we suspect that this is a consequence of the relative inefficiency of this specification.

In column 3, we exclude Bad Health, but we include Good Health. The estimate of the coefficient on Good Health is similar to what we saw in Column 1. The interaction between Good Health and time $t$ unemployment has a point-estimate of -0.001 which is consistent with what we have been seeing. In addition, the interaction between Good Health and time $t-1$ unemployment $\left(\varphi_{1}\right)$ is now insignificant and very close to zero, which is consistent with what we saw before in Tables 2 and 3 . This lends credence to our earlier assertion that the higher pointestimate of $\varphi_{1}$ in column 1 of this table was the consequence of random variation as opposed to something real in the data.

While there is somewhat of an efficiency loss in Table 4, the results in the table are consistent with the results in Tables 2 and 3. Perusing the results in Tables 3 and 4, one sees that the point-estimates are strikingly similar in all three specifications. Thus, we conclude that the only effect of using lagged health measures in this analysis is higher standard errors. The results in Tables 2 and 3 do not appear to be affected in any way by the impact of migration on health.

\section{Conclusions}

In this .paper, we showed that both health and economic conditions are important determinants of an individual's migration decision. First, we provided evidence that poor health creates additional costs which induce selection in migration. In addition, we provided evidence that 
migration is used to insure against business cycle fluctuations. However, we also found that the migration costs which are associated with poor health are sufficiently high that they impede a person's ability to use migration to hedge against economic shocks.

These results suggest that cities and states that experience economic declines also experience an outflow of healthy people which should - ceteris paribus - raise mortality and morbidity rates in depressed areas. This suggests a relationship between recessions and health which is the opposite of Ruhm (2000) who showed that mortality rates are pro-cyclical. Ruhm (2000 and 2005) suggests that the pro-cyclicality of mortality rates may be a causal relationship by providing evidence that, during recessions, tobacco use decreases, height-adjusted weight decreases and leisure time physical activity increases. Ruhm's explanation for this is that temporary economic declines decrease the amount of money that people have to buy tobacco and food, and increase the amount of hours per day that people can potentially use for physical activity. While the results of this .paper and Ruhm's analysis are by-no-means incompatible, our results do suggest that the "healthy living" explanation for the positive effects of recessions on mortality would have to be sufficiently strong to overcome the selective out-migration of healthy people from depressed cities and states.

One issue that warrants further investigation if we are to conclude that Ruhm's results are causal concerns measurement error in mortality rates resulting from migration. Mortality rates for a given period of time are typically calculated using the population of a city, state or country at the beginning of the time period as the denominator and the number of deaths that occur in that location during the time period as the numerator. Thus, in the presence of out-migration (in-migration) from (into) an area, mortality rates will be downwardly (upwardly) biased simply 
because there are fewer (more) people who could possibly die in that location (Abraído-Lanza, et al 1999; Palloni and Arias 2003). This suggests that even in the absence of a "healthy living" effect, we should still expect a negative effect of recessions on mortality due to migration. However, this would be a spurious correlation, not a causal relationship.

\section{References}

[1] Abraído-Lanza, A.F., Dohenwend, B.P., Ng-Mak, D.S. and Turner, J.B., (1999), "The Latino Mortality Paradox: A Test of the 'Salmon Bias' and Healthy Migrant Hypotheses," American Journal of Public Health, 89: 1543-1548.

[2] Blanchard, O.J. and Katz, L. (1992), "Regional Evolutions," Brookings Papers on Economic Activity, No. 1, 1-75.

[3] Borjas, G.J., Bronars, S.G. and Trejo, S.J. (1992), "Assimilation and the Earnings of Young Internal Migrants," Review of Economics and Statistics, 74: 170-175.

[4] Gabriel, P.E. and Schmitz, S. (1994), "Favorable Self-Selection and the Intranational Migration of Young White Males in the United States," Journal of Human Resources, 30: $460-471$.

[5] Halliday, T. (2005), "Selective Migration and Health," unpublished manuscript, University of Hawaii at Manoa.

[6] Hyslop, D.R. (1999), "State Dependence, Serial Correlation and Heterogeneity in Intertemporal Labor Force Participation of Married Women," Econometrica, 67, 1255-1294. 
[7] Idler, E.L. and Kasl, S.V. (1995), "Self-ratings of Health: Do They Also Predict Change in Functional Ability?" Journal of Gerontology, 50, S344-S353.

[8] Kaplan, G.A. and Camacho, T. (1983), "Perceived Health and Mortality: A 9 Year Followup of the Human Population Laboratory Cohort," American Journal of Epidemiology, 177: 292.

[9] Lillard, E.L. and R. Willis (1978), "Dynamic Aspects of Earnings Mobility," Econometrica, 46, $985-1012$.

[10] Meghir, C. and Pistaferri, L. (2005), "Income Variance Dynamics and Heterogeneity," Econometrica, 72, 1-32.

[11] Mossey, J.M. and Shapiro, E. (1982), "Self-rated Health: A Predictor of Mortality Among the Elderly," American Journal of Public Health, 71: 100.

[12] Palloni, A and E. Arias (2003), "A Re-Examination of the Hispanic Mortality Paradox," unpublished manuscript, University of Wisconsin-Madison

[13] Ruhm, C. (2000), "Are Recessions Good for Your Health?" Quarterly Journal of Economics 115: $617-650$.

[14] Ruhm, C.J. (2005), "Healthy Living in Hard Times," forthcoming Journal of Health Economics.

[15] Smith, J. (2003), "SES and Health Over the Life-Course," unpublished manuscript, RAND.

[16] Wooldridge. J. (2000), Econometric Analysis of Cross Section and Panel Data. Cambridge, MA: MIT Press. 
Table 1: Descriptive Statistics

\begin{tabular}{|c|c|c|}
\hline $\begin{array}{c}\text { Variable } \\
\left(\text { Sample Size }{ }^{*}\right)\end{array}$ & Definition & $\begin{array}{c}\text { Mean } \\
\text { (Standard } \\
\text { Deviation) }\end{array}$ \\
\hline $\begin{array}{l}\text { Moved? } \\
(100709)\end{array}$ & $\begin{array}{l}=1 \text { if individual moved between } \\
\text { two time periods }\end{array}$ & $\begin{array}{c}0.058 \\
(0.233)\end{array}$ \\
\hline $\begin{array}{l}\text { Self Reported Health Status } \\
\text { (SRHS) } \\
(109429)\end{array}$ & $\begin{array}{l}\text { Individuals Assessment of Their Own Health } \\
\begin{array}{l}1=\text { Excellent; } 2=\text { Very Good; } 3=\text { Good; } \\
4=\text { Fair; } 5=\text { Poor }\end{array}\end{array}$ & $\begin{array}{l}2.366 \\
(1.084)\end{array}$ \\
\hline $\begin{array}{l}\text { Unemployment Rate } \\
(103526)\end{array}$ & Unemployment Rate in Individual's County of Residence & $\begin{array}{c}6.36 \\
(2.52)\end{array}$ \\
\hline $\begin{array}{l}\text { Age } \\
(110368)\end{array}$ & Individual's Age & $\begin{array}{c}37.89 \\
(11.81)\end{array}$ \\
\hline $\begin{array}{l}\text { Labor Income } \\
(110364)\end{array}$ & $\begin{array}{l}\text { Individual's Labor Income } \\
\text { in } 1983 \text { dollars }\end{array}$ & $\begin{array}{r}13323.70 \\
(16209.11)\end{array}$ \\
\hline $\begin{array}{l}\text { Sex } \\
(110368)\end{array}$ & $=1$ if female & $\begin{array}{l}0.544 \\
(0.50)\end{array}$ \\
\hline $\begin{array}{l}\text { No College Experience } \\
(110152)\end{array}$ & $\begin{array}{l}=1 \text { if the individual never } \\
\text { attended college }\end{array}$ & $\begin{array}{l}0.628 \\
(0.48)\end{array}$ \\
\hline $\begin{array}{l}\text { College Degree } \\
(110152)\end{array}$ & $\begin{array}{l}=1 \text { if the individual has } \\
\text { a college degree }\end{array}$ & $\begin{array}{c}0.20 \\
(0.40)\end{array}$ \\
\hline $\begin{array}{l}\text { White } \\
(106791)\end{array}$ & $=1$ if the individual is white & $\begin{array}{c}0.64 \\
(0.48)\end{array}$ \\
\hline $\begin{array}{l}\text { Black } \\
(106791)\end{array}$ & $=1$ if the individual is black & $\begin{array}{c}0.30 \\
(0.46)\end{array}$ \\
\hline
\end{tabular}


Table 2: Core Empirical Results

\begin{tabular}{|c|c|c|c|c|}
\hline & (1) & (2) & (3) & (4) \\
\hline Good Health $(\gamma)$ & $\begin{array}{l}0.009 \\
(6.09)\end{array}$ & $\begin{array}{l}0.018 \\
(5.02)\end{array}$ & $\begin{array}{l}0.013 \\
(3.71)\end{array}$ & $\begin{array}{l}0.013 \\
(3.59)\end{array}$ \\
\hline Bad Health $(\beta)$ & $\begin{array}{l}-0.002 \\
(-1.14)\end{array}$ & $\begin{array}{l}-0.006 \\
(-1.66)\end{array}$ & $\begin{array}{l}-0.004 \\
(-1.09)\end{array}$ & $\begin{array}{l}-0.004 \\
(-1.05)\end{array}$ \\
\hline Unemployment Rate at Time $t\left(\phi_{0}\right)$ & $\begin{array}{l}-0.002 \\
(-3.61)\end{array}$ & $\begin{array}{l}-0.002 \\
(-1.51)\end{array}$ & $\begin{array}{l}-0.002 \\
(-1.46)\end{array}$ & $\begin{array}{l}-0.002 \\
(-1.50)\end{array}$ \\
\hline Unemployment at Time $t-1\left(\phi_{1}\right)$ & $\begin{array}{l}0.001 \\
(1.58)\end{array}$ & $\begin{array}{l}0.001 \\
(1.05)\end{array}$ & $\begin{array}{l}0.001 \\
(1.19)\end{array}$ & $\begin{array}{l}0.002 \\
(1.30)\end{array}$ \\
\hline Good Health $*$ Unemployment & & -0.002 & -0.001 & -0.001 \\
\hline Rate at Time $t\left(\varphi_{0}\right)$ & - & $(-1.09)$ & $(-0.97)$ & $(-0.91)$ \\
\hline $\begin{array}{l}\text { Good Health } * \text { Unemployment } \\
\text { Rate at Time } t-1\left(\varphi_{1}\right)\end{array}$ & - & $\begin{array}{l}0.0000 \\
(0.10)\end{array}$ & $\begin{array}{l}0.0000 \\
(0.10)\end{array}$ & $\begin{array}{c}0.0000 \\
(0.06)\end{array}$ \\
\hline $\begin{array}{l}\text { Bad Health } * \text { Unemployment } \\
\text { Rate at Time } t\left(\eta_{0}\right)\end{array}$ & - & $\begin{array}{l}0.002 \\
(1.38)\end{array}$ & $\begin{array}{l}0.002 \\
(1.34)\end{array}$ & $\begin{array}{l}0.002 \\
(1.37)\end{array}$ \\
\hline $\begin{array}{l}\text { Bad Health } * \text { Unemployment } \\
\text { Rate at Time } t-1\left(\eta_{1}\right)\end{array}$ & - & $\begin{array}{l}-0.002 \\
(-1.07)\end{array}$ & $\begin{array}{l}-0.002 \\
(-1.07)\end{array}$ & $\begin{array}{l}-0.002 \\
(-1.11)\end{array}$ \\
\hline Worked? ( $=1$ if Labor Income $>0$ ) & - & - & $\begin{array}{l}0.030 \\
(1.39)\end{array}$ & $\begin{array}{c}0.022 \\
(0.99)\end{array}$ \\
\hline Labor Income & - & - & $\begin{array}{l}0.011 \\
(2.17)\end{array}$ & $\begin{array}{l}0.009 \\
(1.71)\end{array}$ \\
\hline Labor Income Squared & - & - & $\begin{array}{l}-0.0009 \\
(-2.87)\end{array}$ & $\begin{array}{l}-0.001 \\
(-2.39)\end{array}$ \\
\hline Age Quadratic? & Yes & Yes & Yes & Yes \\
\hline Sex Dummy? & No & No & Yes & Yes \\
\hline Race Dummies? & No & No & Yes & Yes \\
\hline Education Dummies? & No & No & Yes & Yes \\
\hline Year Dummies? & No & No & No & Yes \\
\hline State Dummies? & No & No & No & Yes \\
\hline$R^{2}$ & 0.011 & 0.011 & 0.015 & 0.026 \\
\hline$H_{0}: \beta=\gamma=0^{* * *}$ & $p=0.000$ & $p=0.000$ & $p=0.000$ & $p=0.000$ \\
\hline$H_{0}: \phi_{0}=\phi_{1}=\eta_{0}=\eta_{1}=\varphi_{0}=\varphi_{1}=0^{* * *}$ & - & $p=0.000$ & $p=0.000$ & $p=0.000$ \\
\hline$H_{0}: \eta_{0}=\eta_{1}=\varphi_{0}=\varphi_{1}=0^{* * *}$ & - & $p=0.000$ & $p=0.003$ & $p=0.004$ \\
\hline$H_{0}: \phi_{0}+\eta_{0}=0^{* * *}$ & - & $p=0.574$ & $p=0.587$ & $p=0.622$ \\
\hline$H_{0}: \phi_{1}+\eta_{1}=0^{* * *}$ & - & $p=0.595$ & $p=0.671$ & $p=0.759$ \\
\hline Individual-Time Observations & 82315 & 82315 & 82145 & 82145 \\
\hline
\end{tabular}

${ }^{*}$ t-statistics are reported in parentheses. All standard errors cluster on individuals.

${ }^{* *}$ The greek letters in paranetheses are the coefficient names for each variable.

${ }^{* * *}$ p-values are reported for the $F$ test of each null. 
Table 3: Alternantive Specifications - Different Partions of SRHS

\begin{tabular}{|c|c|c|c|}
\hline & (1) & (2) & (3) \\
\hline Good Health $(\gamma)$ & $\begin{array}{l}0.013 \\
(3.59)\end{array}$ & - & $\begin{array}{l}0.014 \\
(4.45)\end{array}$ \\
\hline Bad Health $(\beta)$ & $\begin{array}{l}-0.004 \\
(-1.05)\end{array}$ & $\begin{array}{l}-0.012 \\
(-3.48)\end{array}$ & - \\
\hline Unemployment Rate at Time $t\left(\phi_{0}\right)$ & $\begin{array}{l}-0.002 \\
(-1.50)\end{array}$ & $\begin{array}{l}-0.003 \\
(-3.43)\end{array}$ & $\begin{array}{l}-0.001 \\
(-1.01)\end{array}$ \\
\hline Unemployment at Time $t-1\left(\phi_{1}\right)$ & $\begin{array}{l}0.002 \\
(1.30)\end{array}$ & $\begin{array}{l}0.001 \\
(1.96)\end{array}$ & $\begin{array}{l}0.001 \\
(0.93)\end{array}$ \\
\hline $\begin{array}{l}\text { Good Health } * \text { Unemployment } \\
\text { Rate at Time } t\left(\varphi_{0}\right)\end{array}$ & $\begin{array}{l}-0.001 \\
(-0.91)\end{array}$ & - & $\begin{array}{l}-0.002 \\
(-1.69)\end{array}$ \\
\hline $\begin{array}{l}\text { Good Health } * \text { Unemployment } \\
\text { Rate at Time } t-1 \quad\left(\varphi_{1}\right)\end{array}$ & $\begin{array}{r}0.0000 \\
(0.06)\end{array}$ & - & $\begin{array}{l}0.001 \\
(0.58)\end{array}$ \\
\hline $\begin{array}{l}\text { Bad Health } * \text { Unemployment } \\
\text { Rate at Time } t\left(\eta_{0}\right)\end{array}$ & $\begin{array}{l}0.002 \\
(1.37)\end{array}$ & $\begin{array}{l}0.003 \\
(2.20)\end{array}$ & - \\
\hline $\begin{array}{l}\text { Bad Health } * \text { Unemployment } \\
\text { Rate at Time } t-1\left(\eta_{1}\right)\end{array}$ & $\begin{array}{l}-0.002 \\
(-1.11)\end{array}$ & $\begin{array}{l}-0.002 \\
(-1.31)\end{array}$ & - \\
\hline$R^{2}$ & 0.026 & 0.026 & 0.026 \\
\hline $\begin{array}{l}F \text {-test on Unemployment and } \\
\text { Associated Interactions }{ }^{* * *}\end{array}$ & $p=0.000$ & $p=0.000$ & $p=0.000$ \\
\hline $\begin{array}{l}F \text {-test on Unemployment/Health } \\
\text { Interactions*** }\end{array}$ & $p=0.004$ & $p=0.005$ & $p=0.003$ \\
\hline$H_{0}: \phi_{0}+\eta_{0}=0^{* * *}$ & $p=0.622$ & $p=0.618$ & - \\
\hline$H_{0}: \phi_{1}+\eta_{1}=0^{* * *}$ & $p=0.759$ & $p=0.762$ & - \\
\hline Individual-Time Observations & 82145 & 82145 & 82145 \\
\hline
\end{tabular}

*t-statistics are reported in parentheses. All standard errors cluster on individuals.

${ }^{* *}$ The greek letters in paranetheses are the coefficient names

for each variable.

*** p-values are reported for the $F$ test of each null.

${ }^{+}$The regression results in each column of the table include the same control variables in column 4 of Table 2 . 
Table 4: Alternantive Specifications - Lagged Health Measures

\begin{tabular}{|c|c|c|c|}
\hline & $(1)$ & $(2)$ & $(3)$ \\
\hline Good Health at Time $t-1(\gamma)$ & $\begin{array}{l}0.016 \\
(4.13)\end{array}$ & - & $\begin{array}{l}0.014 \\
(4.21)\end{array}$ \\
\hline Bad Health at Time $t-1(\beta)$ & $\begin{array}{l}0.003 \\
(0.75)\end{array}$ & $\begin{array}{l}-0.007 \\
(-1.85)\end{array}$ & - \\
\hline Unemployment Rate at Time $t\left(\phi_{0}\right)$ & $\begin{array}{l}-0.002 \\
(-1.24)\end{array}$ & $\begin{array}{l}-0.002 \\
(-3.02)\end{array}$ & $\begin{array}{l}-0.001 \\
(-1.38)\end{array}$ \\
\hline Unemployment at Time $t-1\left(\phi_{1}\right)$ & $\begin{array}{l}0.002 \\
(1.66)\end{array}$ & $\begin{array}{l}0.001 \\
(1.86)\end{array}$ & $\begin{array}{l}0.001 \\
(1.44)\end{array}$ \\
\hline $\begin{array}{l}\text { Good Health at Time } t-1 * \text { Unemployment } \\
\text { Rate at Time } t\left(\varphi_{0}\right)\end{array}$ & $\begin{array}{l}-0.001 \\
(-0.75)\end{array}$ & - & $\begin{array}{l}-0.001 \\
(-1.15)\end{array}$ \\
\hline $\begin{array}{l}\text { Good Health at Time } t-1 * \text { Unemployment } \\
\text { Rate at Time } t-1\left(\varphi_{1}\right)\end{array}$ & $\begin{array}{l}-0.001 \\
(-0.62)\end{array}$ & - & $\begin{array}{l}-0.0002 \\
(-0.15)\end{array}$ \\
\hline $\begin{array}{l}\text { Bad Health at Time } t-1 * \text { Unemployment } \\
\text { Rate at Time } t\left(\eta_{0}\right)\end{array}$ & $\begin{array}{l}0.001 \\
(0.59)\end{array}$ & $\begin{array}{l}0.002 \\
(1.32)\end{array}$ & - \\
\hline $\begin{array}{l}\text { Bad Health atTime } t-1 * \text { Unemployment } \\
\text { Rate at Time } t-1\left(\eta_{1}\right)\end{array}$ & $\begin{array}{l}-0.002 \\
(-1.30)\end{array}$ & $\begin{array}{l}-0.001 \\
(-1.16)\end{array}$ & - \\
\hline$R^{2}$ & 0.026 & 0.026 & 0.026 \\
\hline $\begin{array}{l}F \text {-test on Unemployment and } \\
\text { Associated Interactions*** }\end{array}$ & $p=0.000$ & $p=0.007$ & $p=0.000$ \\
\hline $\begin{array}{l}F \text {-test on Unemployment/Health } \\
\text { Interactions }\end{array}$ & $p=0.002$ & $p=0.412$ & $p=0.001$ \\
\hline$H_{0}: \phi_{0}+\eta_{0}=0^{* * *}$ & $p=0.5866$ & $p=0.589$ & - \\
\hline $\begin{array}{l}H_{0}: \phi_{1}+\eta_{1}=0^{* * *} \\
\text { Individual-Time Observations }\end{array}$ & $p=0.9733$ & $\begin{array}{l}p=0.977 \\
82145\end{array}$ & $\begin{array}{c}- \\
82145\end{array}$ \\
\hline
\end{tabular}

*t-statistics are reported in parentheses. All standard errors cluster on individuals.

** The greek letters in paranetheses are the coefficient names

for each variable.

${ }^{* * *}$ p-values are reported for the $F$ test of each null.

${ }^{+}$The regression results in each column of the table include the same

control variables in column 4 of Table 2 . 